\title{
Studies on the Distribution of Surface Immunoglobulins
}

\author{
on Human B-Lymphocytes
}

\author{
Kenneth A. Ault, Morris J. Karnovsky, and Emil R. Unanue \\ From the Department of Pathology, Harvard Medical School, \\ Boston, Massachusetts 02115
}

A B S T R A C T Normal human peripheral blood lymphocytes were studied with fluorescent anti-immunoglobulin antibodies and shown to have a patchy distribution of immunoglobulin on their surfaces that does not form a cap after complexing with antibody. Use of freeze-etch electron microscopy confirmed the distribution of immunoglobulin in isolated patches on the membrane. Evidence is presented that this distribution may explain the absence of capping of these human cells as compared with mouse B-lymphocytes.

Studies of the metabolism of antibody bound to the cell surface revealed rapid shedding of complexes from the cell and also rapid endocytosis with subsequent degradation of the antibody.

Several attempts to alter this distribution of immunoglobulin on the surface were unsuccessful. Possible mechanisms by which cell surface elements may be organized are discussed, as well as the significance of the results in terms of the immune response and the classification of certain lymphoproliferative diseases.

\section{INTRODUCTION}

Lymphocytes bearing surface immunoglobulin $(\operatorname{Ig})^{1}$ have been demonstrated in many species, although they have been most studied in the mouse, where they have been shown to be bone marrow-derived (B)-cells. These cells are mainly derived from stem cells in the bone marrow of mammals, or the bursa of Fabricius in birds, and comprise the progenitors of antibody-forming cells $(1,2)$. There have been many reports of similar Ig-bear-

Received for publication 13 March 1973 and in revised form 15 May 1973.

${ }^{1}$ Abbreviations used in this paper: $\mathrm{B}$, bone-marrow derived; BSS, balanced salt solution; FCS, fetal calf serum; FITC, fluorescein isothiocyanate; FNPS, difluorodinitrodiphenylsulfone; PBL, peripheral blood lymphocyte; RaHGG, rabbit antihuman gamma globulin antibody; TCA, trichloroacetic acid. ing lymphocytes in the human $(3,4)$. Both from the results of studies on human immune deficiency states (5-7) and by analogy with mouse Ig-bearing lymphocytes, these human cells are also thought to be B-cells, mediating primarily humoral immune response.

Recent studies on mouse B-lymphocytes have demonstrated that the Ig on the cell surface is not fixed, but rather is mobile upon combination with anti-Ig antibodies forming complexes of diverse sizes on the cell surface, which may move toward one pole of the cell. This last phenomenon, "capping," has been shown to be dependent on temperature, and, very critically, on the amount and distribution of $\operatorname{Ig}$ on the cell surface $(8,9)$, which in turn dictates the amount of cross-linking achievable by various ligands; it is also dependent on cell metabolism (10-12). Indeed, while anti-Ig antibody stimulates prompt capping of $\mathrm{Ig}$ on B-lymphocytes, anti H-2 antibody, for example, provokes no capping on thymocytes. Comparison of the distribution of these two antigens on the cell surface shows the Ig distributed evenly, in a reticular, random pattern, but the $\mathrm{H}-2$ located in widely separated patches, so far apart from each other that they cannot be cross-linked by antibodies. Complexes of anti-H-2-H-2 antigens tend to aggregate on the surface with time but these will usually not terminate in a cap.

After their redistribution the surface complexes may follow three pathways: being shed from the cell surface, internalized by endocytosis, or, in a small amount, left on the surface. A large fraction of internalized surfacebound anti-Ig is effectively degraded by the cell (13). The functional significance in the immune response of capping, shedding of immune complexes, and degradation of intermediate complexes is as yet unknown.

These studies were undertaken to investigate the normal human B-lymphocyte in the light of this knowledge. The behavior of surface Ig on human B-cells may be of significance both in understanding the normal immune 
response and in classifying lymphoproliferative diseases. A number of previous reports have described considerable differences in the number of Ig-bearing cells, their class specificity, and the amount of Ig on the cell surface in normal and neoplastic lymphocytes. These differences might be expected to be reflected in the way such cells handle surface-bound antibody.

Many similarities to and certain fundamental differences from mouse cells have been observed. The use of fluorescent labeling and freeze-etch electron microscopic techniques in these studies reveals a pattern of Ig on the human lymphocyte that differs from that of the mouse; however, the metabolism of radiolabeled anti-Ig antibody is substantially the same. Attempts to alter the surface distribution of Ig with several agents in an effort to reveal the basis for the distribution pattern observed were not successful.

\section{METHODS}

Cell preparation. Peripheral blood lymphocytes (PBL) were isolated from fresh heparinized blood drawn from normal donors (laboratory personnel aged 21-40). In the initial experiments whole blood was passed over an equal volume of $0.3-\mathrm{mm}$ glass beads (VirTis Co., Inc., Gardiner, $\mathrm{N}$ Y.) packed in a column and washed through with an equal volume of Hanks' balanced salt solution (BSS) with $5 \%$ fetal calf serum (FCS), $10 \mathrm{mM}$ HEPES ( $N$-2-hydroxyethylpiperazine- $N$-2-ethane sulfonic acid) (Microbiological Associates, Inc., Bethesda, Md.), and $5 \% \mathrm{NaHCO}_{3}$ at room temperature in order to remove the majority of platelets. In later experiments the blood was defibrinated by stirring without exposure to glass beads and then diluted with the same medium. No differences in Ig distribution were noted in cells prepared by the two methods; cell yields were similar, but the second method was more efficient in removing platelets. Lymphocytes were isolated using a gradient of Ficoll (Pharmacia Fine Chemicals, Inc., Uppsala, Sweden and Hypaque (Winthrop Laboratories, Div. of Sterling Drug, N. Y.) according to the method of Perper, Zee, and Mickelson (14) and washed three times in medium containing $10 \%$ FCS. Typical preparations contained 92 to $96 \%$ lymphocytes, $2-5 \%$ monocytes, and $2-4 \%$ polymorphonuclear leukocytes with $100 \%$ viability as judged by their exclusion of trypan blue.

Antibody preparation. Most of the experiments were made with two different polyvalent rabbit anti-human globulin (RaHGG) preparations, both of which gave the same results. RaHGG was prepared from rabbits repeatedly immunized with human Fraction II (Pentex Biochemical, Kankakee, I11.) in Freund's complete adjuvant (Difco Laboratcries, Detroit, Mich.). Rabbits were immunized four to six times with about $8 \mathrm{mg}$ of HGG and bled usually 2 wk after the last booster injection. Antibody preparations were all DEAE cellulose column fractions containing only IgG, and specificity was demonstrated by immunoelectrophoresis. Fluorescein isothiocyanate (FITC) conjugation was by standard techniques with a molar fluorescein to protein ration of from 2 to 7 . A sample of RaHGG was absorbed by stirring overnight at $4^{\circ} \mathrm{C}$ with a slurry of Sepharose 4B (Pharmacia Fine Chemicals, Inc., Piscataway, N. J.), to which human gamma globulin had been coupled using cyanogen bromide (Eastman Kodak Co., Inc., Rochester,
N. Y.) by a method detailed in reference 15 . The resulting antibody preparation gave no precipitin line on immunoelectrophoresis and gave no fluorescent staining of human lymphocytes. Fluorescence studies were done using an optimal dose of $15 \mu \mathrm{g}-100 \mu \mathrm{g}$ of FITC-RaHGG/5 $\times 10^{\circ}$ cells in $200 \mu 1$. Antisera specific for human IgM, IgG, and $\kappa$-chains were the kind gift of Dr. Hans L. Spiegelberg. Goat antisera to rabbit Ig was prepared by repeated immunization with $5-10 \mathrm{mg}$ of rabbit IgG in complete Freund's adjuvant.

Preparation of monovalent Fab fragment of RaHGG was carried out by the method of Porter (16), using papain digestion followed by removal of $\mathrm{Fc}$ fragments by crystalization and further purification on a carboxymethylcellulose column. The resulting preparation no longer formed precipitin lines in double-diffusion agar tests by Ouchterlony technique.

Fluorescence labeling of cells. Fluorescence studies were carried out by incubating $5 \times 10^{6}$ cells with various amounts of FITC-labeled antibody in a volume of $200 \mu \mathrm{l}$ for 30 min at $4^{\circ} \mathrm{C}$, then washing them three times, and examining the cells in a Zeiss microscope (Carl Zeiss, Inc., N. Y.) with an FITC primary filter. (Optick Laboratorium, Lyngby, Denmark). Cells were handled carefully in an ice bath and a refrigerated centrifuge to prevent any warming that might alter cell surface distributions. In the case of double-layer "sandwich"-labeling experiments a second incubation identical to the first was carried out with the second reagent before observing the cells. 300-500 cells were routinely counted to determine the percentage of labeled cells. In some experiments the washed cells, after incubation at $4^{\circ} \mathrm{C}$, were placed in a suitable volume of medium at $37^{\circ} \mathrm{C}$ and aliquots removed at specified times for immediate examination. Incubations longer than $60 \mathrm{~min}$ were routinely carried out in a $5 \% \mathrm{CO}_{2}, 100 \%$ humidity incubator. At the end of such incubation viability exceeded $90 \%$ whenever checked.

Fixation of cells. PBL's were fixed either before or after being stained with FITC-RaHGG by suspension in $1 \%$ paraformaldehyde in $0.1 \mathrm{M}$ cacodylate buffer for either $5 \mathrm{~min}$ at $37^{\circ} \mathrm{C}$ or $10 \mathrm{~min}$ at $0^{\circ} \mathrm{C}$. They were then washed and examined.

Fate of radiolabeled $\mathrm{RaHGG}$. ${ }^{125} \mathrm{I}$ conjugation of $\mathrm{RaHGG}$ was done by the lactoperoxidase method of Marchalonis (17), with enzyme prepared by Dr. Howard Engers in this laboratory. Labeled reagents had specific activities of $1-5 \mu \mathrm{Ci} / \mu \mathrm{g}$ with $90 \%$ of the activity precipitable with cold trichloroacetic acid (TCA).

Studies of the metabolism of $\left[{ }^{125} \mathrm{I}\right] \mathrm{RaHGG}$ were done using the same incubation methods described above, i.e., at $4^{\circ} \mathrm{C}$ for $30 \mathrm{~min}$ followed by five washes in medium. All glassware was siliconized and the cells were transfered to fresh tubes between the third and fourth washes to eliminate radioactivity adherent to the glass. At this time an aliquot of the cells was measured for radioactivity in order to determine the total amount of label bound to the cells; the cells were then incubated at a concentration of $10^{7} / \mathrm{ml}$ at $37^{\circ} \mathrm{C}$ for varying lengths of time, in $5 \% \mathrm{CO}_{2}$ and $100 \%$ humidity. Examination of such labeled cell preparations by radioautography (using Ilford L-4 liquid emulsion, Ilford Ltd., Ilford, Essex. England, and routine procedures) revealed label on about $25 \%$ of the lymphocytes, only occasional grains on polymorphonuclear leukocytes, and no grains over platelets. After incubation the cells were separated from the supernatant medium by centrifugation at $1,500 \mathrm{~g}$ for $30 \mathrm{~min}$. The radioactive content was measured on both cells and supernate; also an aliquot of the latter was 
precipitated in $10 \% \mathrm{TCA}$ at $4^{\circ} \mathrm{C}$ with $50 \mu$ of normal rabbit serum as a carrier in order to determine protein-bound and nonprotein-bound ${ }^{125} \mathrm{I}$. Another aliquot was placed on a 5$20 \%$ sucrose gradient according to the methods of Martin and Ames (18) and centrifuged for $18 \mathrm{~h}$ at $39,000 \mathrm{rpm}$ $(190,000 \mathrm{~g})$ in a Beckman SW-50 rotor (Beckman Instruments, Inc., Spinco Div., Palo Alto, Calif.) Fractions of $0.1 \mathrm{ml}$ each were collected and counted.

Special cell treatments. Rabbit and goat anti-human $\mathrm{Clq}$ serum were kindly supplied by Dr. Peter Schur, (Robert Breck Brigham Hospital, Boston, Mass.) after preparation from purified human $\mathrm{Clq}$; their specificity was demonstrated by immunoelectrophoresis. In our laboratory they were passed over a DEAE column, eluted with $0.0175 \mathrm{M}$ phosphate buffer, $\mathrm{pH} 7.5$, and the resulting IgG fraction was conjugated to FITC in the usual way. This was used to treat PBLs directly in the same method used for FITC$\mathrm{RaHGG}$, in doses ranging from 100 to $500 \mu \mathrm{g} / 5 \times 10^{6}$ cells. In one experiment in an attempt to replace any $\mathrm{Clq}$ that might have been lost from the cells during preparation, the PBLs were preincubated for $30 \mathrm{~min}$ at $4^{\circ} \mathrm{C}$ in $1 \mathrm{~cm}^{3}$ whole iresh autologous serum. They were then spun down, the serum decanted, and the fluorescent anti-Clq added in 200 $\mu 1$, incubated for $30 \mathrm{~min}$ at $4^{\circ} \mathrm{C}$, washed once, and examined.

Treatment of cells with trypsin was accomplished by suspending $5 \times 10^{8}$ cells in given concentrations of trypsin (Sigma Chemical Co., St. Louis, Mo.), freshly prepared in BSS with no added FCS. The cells were incubated in $1 \mathrm{ml}$ for the specified length of time at $37^{\circ} \mathrm{C}$, and then $3 \mathrm{ml}$ of BSS with $10 \%$ FCS and $1 \mathrm{mg} / \mathrm{ml}$ of soybean trypsin inhibitor (Sigma) were added, and the cells centrifuged and washed twice more with BSS with $10 \%$ FCS The cells were then stained with FITC-RaHGG as described above.

Treatment of cells with EDTA was done by suspending the cells in $1 \mathrm{ml}$ of the given concentration of EDTA dissolved in calcium- and magnesium-free BSS with $10 \%$ FCS. The cells were incubated for $30 \mathrm{~min}$ at $4^{\circ} \mathrm{C}$, washed once with the same medium, and then tested with fluorescent antibody, still in the presence of the same concentration of EDTA.

Treatment with colchicine was done by preincubating the cells for $30 \mathrm{~min}$ at $4^{\circ} \mathrm{C}$ in the colchicine (Sigma) dissolved in $\mathrm{BSS}$ with $10 \% \mathrm{FCS}$, then staining and washing the cells in the presence of the colchicine as described above.

Ferritin labeling. Ferritin (Pentex) was trace-labeled vith ${ }^{125} \mathrm{I}$ and RaHGG was labeled with ${ }^{131} \mathrm{I}$ with chloramine $\mathrm{T}$ (Kodak). Conjugation of ferritin to RaHGG was done according to the method of Ram, Tawde, Pierce, and Midgley (19) with difluorodinitrodiphenylsulfone (FNPS). $20 \mathrm{mg}$ of globulin and $55 \mathrm{mg}$ of ferritin were dissolved in $2 \%$ $\mathrm{Na}_{2} \mathrm{CO}_{3}$ and $0.25 \mathrm{ml}$ of FNPS $5 \%$ in acetone was added dropwise at $4^{\circ} \mathrm{C}$. Stirring was continued overnight at $4^{\circ} \mathrm{C}$ The solution was dialyzed for 3 days against $\mathrm{pH} 7$ phosphate-buffered saline and then centrifuged to remove prec1pitated proteins $(7500 \mathrm{~g}$ for $30 \mathrm{~min})$. The conjugate was separated from unconjugated RaHGG and free ferritin by preparative electrophoresis on Pevikon (Mercer Chemical Co., N. Y.) ( $300 \mathrm{~V}$ and $40 \mathrm{~mA}$ ). The conjugate after elution and concentration was counted for the two isotopes and shown to contain a molar ratio of ferritin to globulin of 0.7 .

Freeze-etch electron microscopy. Cells were prepared for electron microscopic examination by treating $10^{7}$ PBLs with either 100 or $400 \mu \mathrm{g}$ of RaHGG conjugated to ferritin for $30 \mathrm{~min}$ at $4^{\circ} \mathrm{C}$ and then washing three times. One sample of cells was then warmed to $37^{\circ} \mathrm{C}$ for $15 \mathrm{~min}$, returned to $4^{\circ} \mathrm{C}$, then washed again and fixed. Strict attention was paid to keep the cells cold throughout their handling.

Fixation was for $15 \mathrm{~min}$ in $1 \%$ glutaraldehyde in $0.1 \mathrm{M}$ cocodylate buffer, $\mathrm{pH} 7.3$ at $4^{\circ} \mathrm{C}$. The cells were washed twice in the buffer and then washed once in $0.017 \mathrm{M}$ Tris $\mathrm{HCl} \mathrm{pH} \mathrm{7.4.} \mathrm{After} \mathrm{centrifugation} \mathrm{at} 300 \mathrm{~g}, 3 \mathrm{ml}$ of distilled water was added to the pellet and the cells were resuspended and respun at $500 \mathrm{~g}$. The supernate was decanted and the specimen transferred to Balzers specimen holders (Balzers High Vacuum Corp., Santa Ana, Calif.) and rapidly frozen in Freon 22 (E. I. du Pont de Nemours \& Co., Inc., Wilmington, Del.) cooled with liquid nitrogen. The specimens were then cleaved, etched for 5 to $30 \mathrm{~min}$ at $-104^{\circ} \mathrm{C}$ in a Balzers high vacuum freeze-etch unit BA 360 M (Balzers High Vacuum Corp.), and shadowed with platinum at an angle of $45^{\circ}$. The replicas were strengthened by evaporation of carbon at an angle of $90^{\circ}$ and thawed, and the cells were digested away from the replica with hypochlorite (Chlorox). The replicas were mounted on grids and examined by conventional transmission electron microscopy in an AEI-801 electron microscope (AEI Scientific Apparatus Inc., Elmsford, N. Y.) at $60 / 80 \mathrm{kV}$ and $30-40$ $\mu \mathrm{M}$ objective apertures.

Comparison with mouse cells. In several experiments murine spleen and peripheral blood lymphocytes were examined by identical methods. We have observed no differences in the behavior of surface immunoglobulin from these two sources in the mouse. The fluorescent reagents used have been described (9). The results of the experiments were the same as reported previously and are mentioned here for purposes of comparison.

\section{RESULTS}

Fluorescent staining pattern with anti-Ig antibodies. Examination of PBLs with increasing doses of polyvalent FITC-RaHGG showed progressive increase in intensity of staining and in number of cells stained until an apparent saturation point was reached (Fig. 1) and

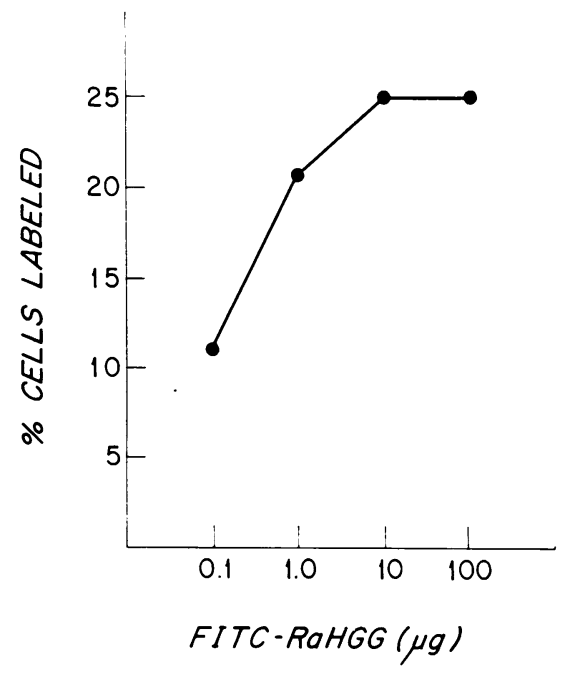

FIgURE 1 Saturation of Ig-bearing cell population. Data shown are for one individual: the percentage varies from person to person but has not exceeded $25 \%$ of peripheral lymphocytes in our experiments. 

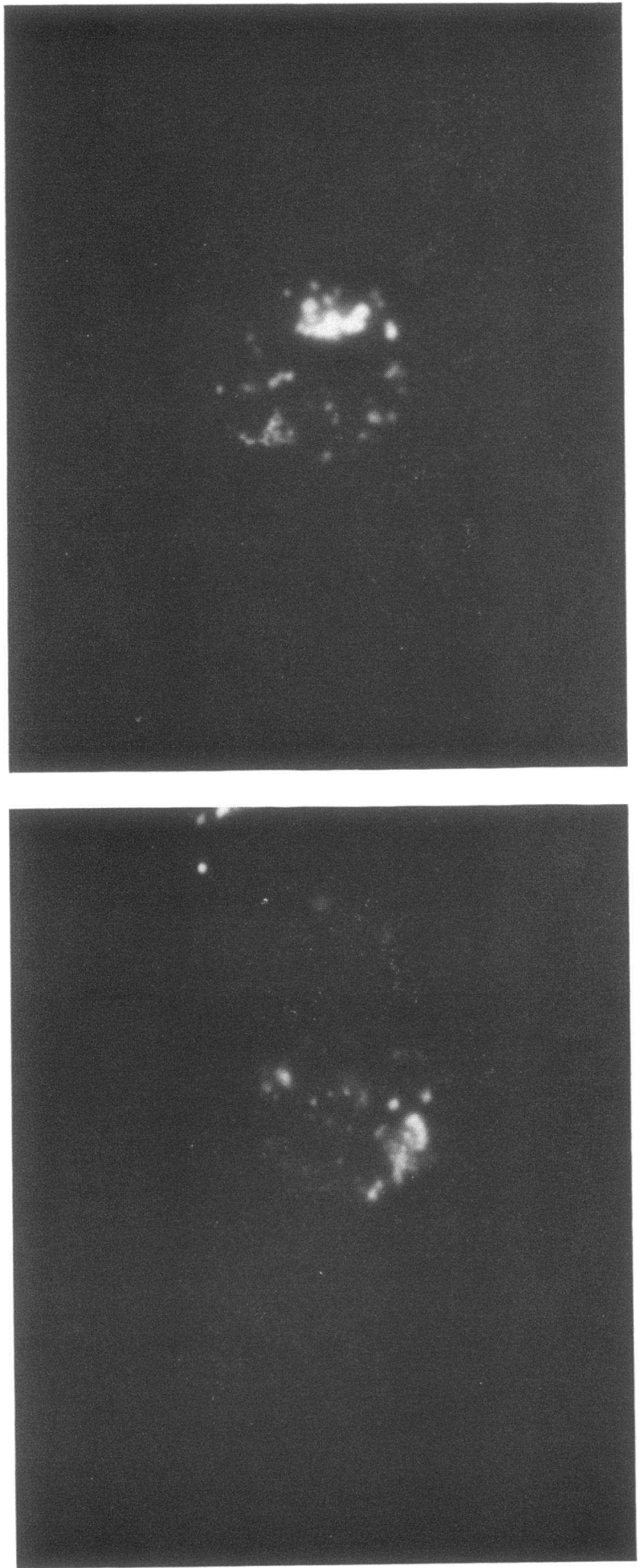

FIgURE 2 Two examples of cells stained with FITCRaHGG and subsequently warmed to $37^{\circ} \mathrm{C}$ for $20 \mathrm{~min}$. Photographs taken of dried cells mounted in glycerin. Original magnification $400 \times$. It was not possible to obtain at that point the number of positive cells remained constant. For all subsequent studies a dose of fluorescent antibody was chosen that gave the maximum number of positive cells.

A striking granularity of the staining distribution of Ig was observed in PBLs that was quite distinct from that seen on mouse lymphocytes stained also with polyvalent rabbit anti-mouse globulin. This granularity was noted on nearly all of the positive cells despite the fact that they had been maintained strictly at $4^{\circ} \mathrm{C}$ throughout their preparation. On incubation at $37^{\circ} \mathrm{C}$ the staining became increasingly granular with the formation of large aggregates of fluorescence on the cell surface (Fig. 2). With further incubation both the intensity and the number of positive cells gradually declined so that after $1 \mathrm{~h}$ about one half of the cells had lost all label and much of the remaining fluorescence was located in small dots that appeared to be within the cellular cytoplasm. This staining pattern has been associated with endocytosis of material into the Golgi region in mouse cells (20). By making serial observations during the $37^{\circ} \mathrm{C}$ incubation, it was determined that the majority of normal human PBLs did not form caps such as are seen in nearly $100 \%$ of mouse Ig positive cells. Usually cells (about $1 \%$ of the total) with recognizable typical caps could be seen; however the majority formed two or more large aggregates on their surface. Although some cells had a single aggregate resembling a cap it seemed likely that such cells arose by loss of the remainder of the complexes (whether by endocytosis or shedding) rather than by coalescence at one pole of the cell. Over the course of these experiments cells from eight normal individuals were examined and in each case, although the percentage of positive cells varied from 9 to $25 \%$, the staining pattern and behavior on warming was identical. Indeed, the lack of analogy between the capping phenomenon seen in murine spleen or peripheral blood lymphocytes and the pattern seen on human cells was striking. In the mouse it was possible to observe a continuum of intermediate states between a circumferentially stained cell and a capped cell. No such continuum was seen in human PBLs.

Cells stained with antisera specific for $\boldsymbol{\kappa}$-determinants showed behavior of aggregates identical with those stained with polyvalent RaHGG. About $75 \%$ of the Ig positive cells were labelled with anti- $\kappa$. Similarly cells stained with anti-IgM and anti-IgG showed patterns of aggregation indistinguishable from those obtained with the other reagents. Our anti-IgM serum stained about $70 \%$ of the positive cells and our anti-IgG serum, con-

clear photographs of the finely granular pattern seen in unwarmed cells or cells labeled with Fab fragments due to the low intensity of fluorescence. 


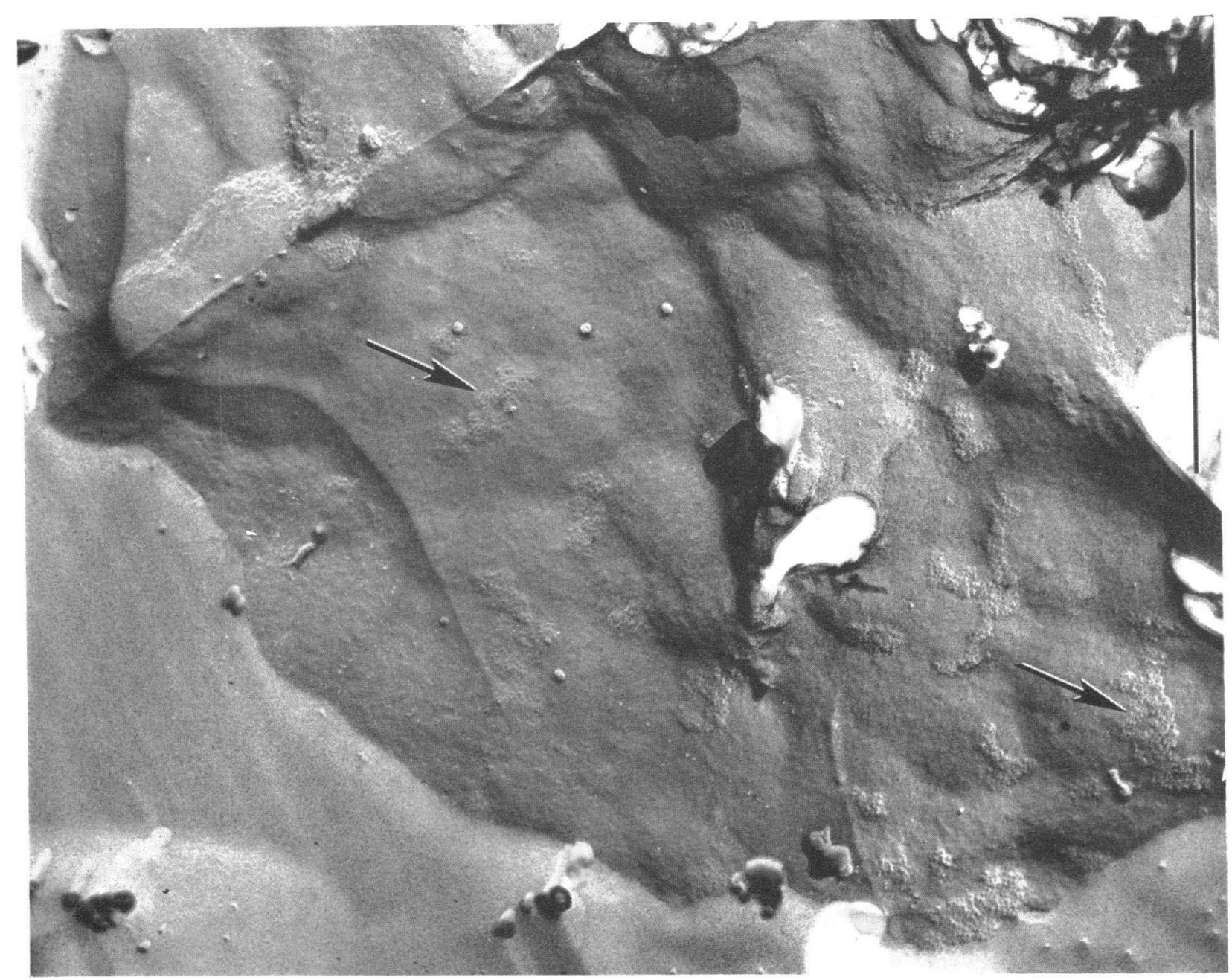

FIGURE 3 Freeze-etched preparation of surface of human B-lymphocyte labeled with saturating dose of RaHGG coupled to ferritin. Ig is revealed as discrete domains of ferritin labeling (arrows) separated by large areas of blank surface membrane. Original magnification $25,000 \times$. Bar represents $1 \mu \mathrm{M}$.

taminated by an anti- $\kappa$ component, stained the same number of cells as did the polyvalent RaHGG.

Use of RaHGG absorbed by passage over an HGGcoated Sepharose column gave no staining of cell surfaces, thus demonstrating its specificity.

FITC-labeled Fab fragment of RaHGG was used to stain cells to assess the role of the ability of the ligand to cross-link surface Ig on the formation of aggregates. This reagent gave much less intense staining that rapidly decayed on warming of the cells. However, a granular pattern of staining could be seen in cells maintained at $4^{\circ} \mathrm{C}$ that was qualitatively similar to that seen with bivalent RaHGG. However, no large aggregate formation took place with the monovalent antibody upon incubation at $37^{\circ} \mathrm{C}$.

When PBLs were fixed with paraformaldehyde at $0^{\circ} \mathrm{C}$ before being stained with FITC-RaHGG, the granu- lar fluorescence pattern was identical with that seen in unfixed cells; however, such fixed cells did not form large aggregates when warmed to $37^{\circ} \mathrm{C}$. In addition cells first stained with antibody and then fixed at $0^{\circ} \mathrm{C}$ continued to show a finely granular pattern with no aggregation on being warmed. Thus it appeared that fixation did not of itself significantly alter the pattern of Ig on the surface, but it did prevent any subsequent motion of Ig. A similar observation has also been made at the electron microscopy level for concanavalin A-binding sites on fibroblasts. ${ }^{2}$

Cells were also fixed after being warmed to $37^{\circ} \mathrm{C}$ for $15 \mathrm{~min}$. After fixation they were cooled to $0^{\circ} \mathrm{C}$ and stained. These cells showed the same finely granular pattern seen with unfixed cells.

\footnotetext{
'Rosenblith, J., and M. J. Karnovsky. Manuscript in preparation.
} 
Electron microscopy studies. Thus, results of studies with fluorescent reagents indicated that the majority of human B-lymphocytes did not redistribute their surface $\mathrm{Ig}$ into caps after complexing with a ligand. The clear granularity in distribution of $\mathrm{Ig}$, which redistributed into larger aggregates, suggested that Ig might be spaced differently on the human cell than on the mouse lymphocyte. This was confirmed using freeze-etch electron microscopic techniques, which demonstrated patches of ferritin-labeled antibody separated by several thousand angstroms of bare membrane (Fig. 3). This pattern was seen with doses of antibody judged to be in excess based on fluorescent studies and was the same regardless of the dose of antibody used over the range of

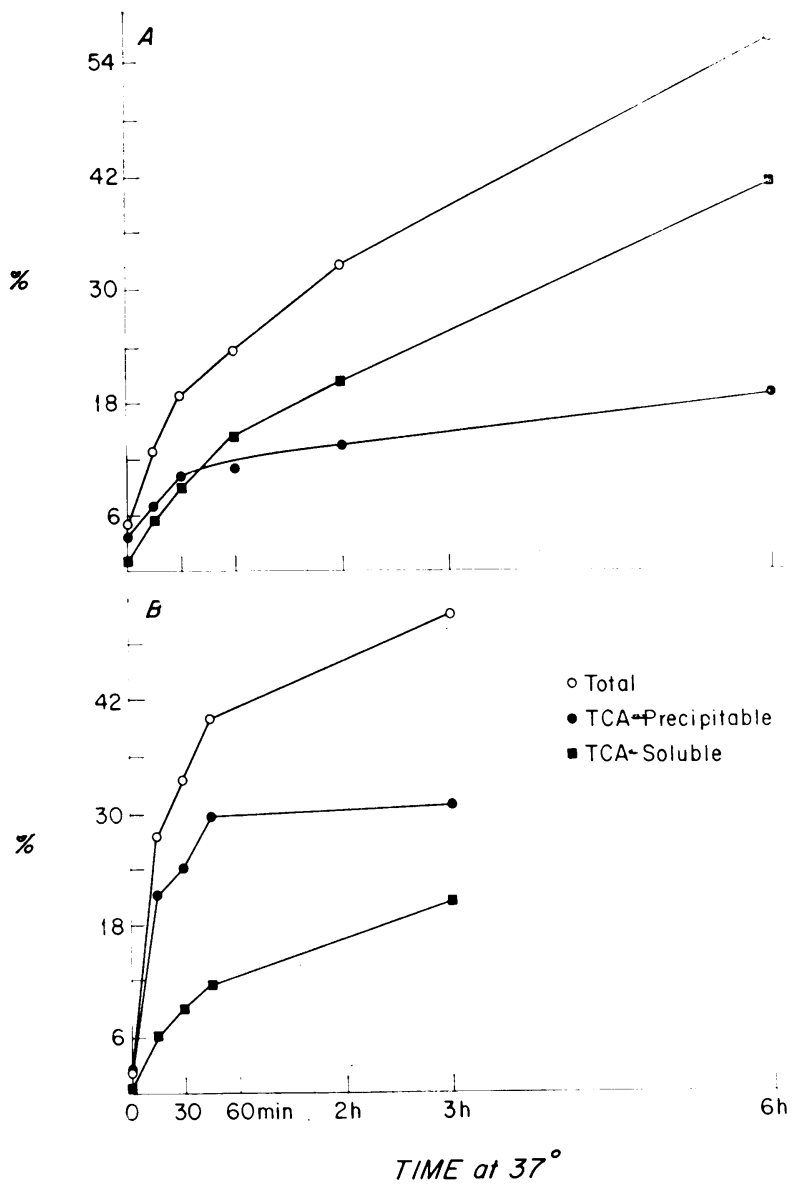

Figure 4 Release of ${ }^{125}$ I-labeled RaHGG from lymphocytes, expressed as a percent of the counts originally bound to the cells. A and B represent results from two different antibody preparations and illustrate that, although the appearance of TCA-soluble material proceeds at the same pearance of TCA-soluble material proceeds at the same pace, the early re antibody used in B. In both cases the release of TCA-precipitable counts has essentially stopped by $1 \mathrm{~h}$.
$100-400 \mu \mathrm{g}$ of antibody $/ 10^{7}$ cells. Dr. Howard Grey ${ }^{3}$ has determined the amount of $\mathrm{Ig}$ on the normal human lymphocyte to be from 11 to $21 \mathrm{ng} / 10^{8}$ cells. Data obtained by using radiolabeled RaHGG at a dose of $100 \mu \mathrm{g} / 10^{7}$ cells indicate that there should be an adequate number of anti-Ig molecules bound to saturate all the available Ig sites. It seems likely therefore that the pattern observed did not result from failure to saturate available Ig sites. Thus, the patchy distribution of $\mathrm{Ig}$ sites correlated well with fluorescence observations and closely resembled the pattern of $\mathrm{H}-2$ antigen sites on the mouse thymocyte, which are known not to demonstrate capping.

Occasionally a cell was seen on which the pattern of ferritin anti-Ig antibody was diffuse and reticular, exactly like that of the mouse lymphocyte. Although the exact frequency of these cells could not be estimated due to sampling error at the electron microscopy level, the possibility that these cells are the same as those few cells that cap and may represent a distinct population of $\mathrm{B}$-lymphocytes is attractive.

Cells warmed to $37^{\circ} \mathrm{C}$ for 15 min after being labeled with ferritin-RaHGG demonstrated very little label remaining on the surface, thus confirming our impression that shedding and rapid endocytosis are predominant at $37^{\circ} \mathrm{C}$.

Metabolism of surface-bound anti-Ig. PBLs were treated with ${ }^{125}$ I-labeled $\mathrm{RaHGG}$ as described above. After five washings at $4^{\circ} \mathrm{C}$ the amount of radioactivity released per wash was less than $5 \%$ of the total. Release of cell-bound radioactivity was followed in the supernatant medium as a function of time during incubation at $37^{\circ} \mathrm{C}$. Fig. 4 shows the release into the culture fluids of total ${ }^{125} \mathrm{I}$ counts, and TCA-soluble and TCAprecipitable counts expressed as the percent of the total counts initially bound to the cells at $4^{\circ} \mathrm{C}$. It can be seen that there was a very rapid release of counts early in the incubation, which then became more gradual with time. The magnitude of this early release varied with different antibody preparations as shown. Almost all of the TCAprecipitable counts were released within the 1 st h. However TCA-soluble counts continued to rise, accounting for an increasing proportion of the total counts released, while TCA-precipitable counts leveled off. This timecourse was independent of the dose of antibody originally applied to the cells over the range from $10 \mu \mathrm{g}$ to $1 \mathrm{mg}$, representing a 10 -fold range in counts bound per cell (not shown in Fig. 4).

These results confirm the impression obtained from fluorescent labeling that there is an early loss of label from the cell; in addition, the gradual appearance of TCA-soluble label indicates degradation of the antibody, probably from endocytosis and catabolism of the com-

\footnotetext{
"Personal communication.
} 
plexes. Examination of the supernate radioactivity by sucrose density gradient centrifugation (Fig. 5) showed that early supernates contained a peak corresponding to the original antibody, and in addition a peak migrating ahead of the antibody that probably represents antiIg-surface Ig complexes shed from the cell surface. Later supernates (Fig. 3) showed no change in the site of the monomeric antibody peak but the appearance of a large amount of heterogenous slowly sedimenting label. Part of this low-density material, which is on the top of the gradient, corresponds to the TCA-soluble label and part is degraded Ig sedimenting slower than monomeric Ig.

Both the release of label from the surface and its degradation are similar to that seen in mouse lymphocytes and occur with roughly the same time-course. Calculation of the areas under the sucrose gradient curves gives an estimate of approximately $8 \%$ of the cell-bound antibody released in the first $60 \mathrm{~min}$ as material that sediments with or faster than the original antibody, whereas the corresponding figure for mouse cells is $3-4 \%$ (13).

Attempts to alter the distribution of surface immunoglobulin. Attempts were made to treat the cells by various means in order to gain some insight into the mechanism by which they maintain the patchy distribution of Ig sites on their surface. There seem to be two basic mechanisms to be considered: either some influence extrinsic to the cell, perhaps a protein that could bind together Ig and thus create the patches on an otherwise fluid membrane, or some intrinsic or structural property of the membrane itself.

Likely candidates for an extrinsic influence included the first component of complement, which is capable of binding together Ig molecules, or some other protein on the surface. PBLs did not react with our fluorescent anti-C1q. This was also investigated by treating the cells with whole fresh human serum in the cold and then, without washing, examining with fluorescent antiC1q. With multiple doses it was impossible to demonstrate any fluorescence on lymphocytes.

The PBLs were also treated with varying doses of trypsin. Use of regimens varying from $0.01 \mathrm{mg}$ of tryp$\mathrm{sin} / \mathrm{ml}$ for $2 \mathrm{~min}$ at $37^{\circ} \mathrm{C}$ to as much as $0.1 \mathrm{mg} / \mathrm{ml}$ for $15 \mathrm{~min}$ before staining with FITC-RaHGG caused a progressive loss of surface Ig with decrease in number of positive cells and decrease in intensity of staining, but no fundamental difference in the granular distribution or the lack of capping could be detected. It was noted that with treatments that removed nearly all of the surface Ig, sparing only about $6 \%$ of the cells, many of those remaining positive appeared to have normal staining intensity. These apparently trypsin-resistant cells contained approximately equal numbers of IgG-

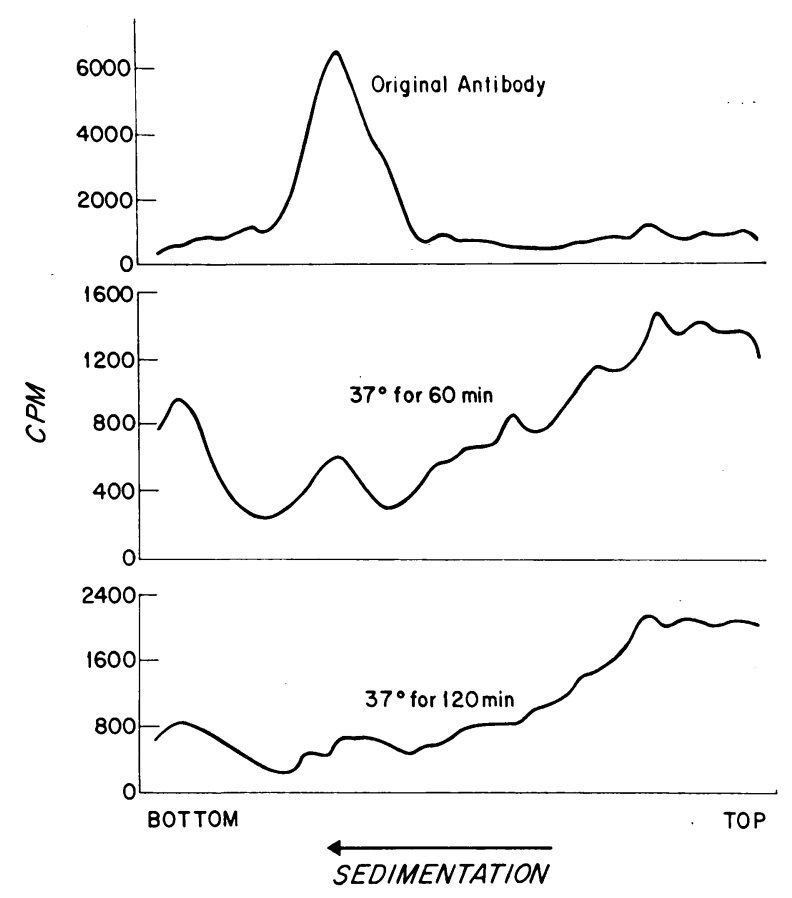

Figure 5 Sucrose gradient analysis of the material released into the supernate by the cells labeled with $\left.{ }^{125} \mathrm{I}\right]$ RaHGG and then incubated at $37^{\circ} \mathrm{C}$ for various times. At $60 \mathrm{~min}$ there is a definite peak of heavy material sedimenting near the bottom and a large amount of diffuse slowly sedimenting material. The light material continues to increase in amount at $2 \mathrm{~h}$ of incubation.

and IgM-bearing cells and thus do not seem to be of one class-specificity. This once again seems to be evidence for a subpopulation of cells that have more Ig on their surfaces, a different distribution of Ig, or both.

A similar attempt was made to alter the surface with EDTA in $\mathrm{Ca}$ - and $\mathrm{Mg}$-free $\mathrm{BSS}$, to see if divalent cations in some way might participate in holding Ig sites in place on the membrane. Pretreatment with concentrations of EDTA from $0.01 \mathrm{M}$ to $0.1 \mathrm{M}$ resulted in no significant alteration in Ig pattern as determined by fluorescence. At the high dose there was considerable cell death, and at the lower dose the granular pattern was present and capping was not increased; endocytosis appeared to procede normally.

In an attempt to alter the membrane structure by disrupting intrinsic structures, the cells were pretreated with colchicine in doses ranging from $10^{-5} \mathrm{M}$ to $10^{-3} \mathrm{M}$, treated for $\frac{1}{2} \mathrm{~h}$ at $4^{\circ} \mathrm{C}$, and then stained and examined in the presence of the same amount of colchicine. Again there was no effect on the granularity of the staining or the frequency of capping. Ukena and Berlin have reported apparent alterations in the topography of menbrane transport sites with colchicine treatment (21). 


\section{DISCUSSION}

These studies confirm and extend the impressions of others that human Ig-bearing lymphocytes are in most respects similar to those of the mouse and other species. Several others have mentioned that human lymphocytes did not form caps in large numbers, or that they formed large aggregates on their surfaces on being warmed $(4-6,22) .{ }^{4}$ However, there have been no detailed studies of this phenomenon. We have tried to document these observations in detail and to provide some basis for understanding such variations.

The property of carrying Ig on the cell surface is felt to be related to the ability of these cells to bind antigen, and interaction that is certainly an integral part of the immune response. The exact requirements for the interaction of B-cells with antigen as well as the sequelae of this binding remain speculative. By analogy with the interaction of Ig and anti-Ig on the surface it seems that there are several possible sequels to ligand binding to Ig. The complexes can dissociate and be lost from the surface; they can be redistributed on the surface; they can be shed off, endocytosed, and then degraded; or they can remain on the surface (8). It is not possible to say which, if any, of these will prove to be important in triggering events after the recognition of antigen; however, by examining different species it is at least possible to find those mechanisms that occur universally and those that may be peculiar to individual species.

Human B-lymphocytes are capable of binding and subsequently metabolizing anti- $\mathrm{Ig}$, and indeed, they rapidly lose a major portion of complexes from the surface. By analogy with mouse cells, it is most likely that internalization by endocytosis precedes degradation (9). These processes do not differ significantly from those in the mouse and may be general properties of all B-lymphocytes. In contrast, most human lymphocytes do not redistribute the complexes of Ig-anti-Ig into caps but rather into disseminated aggregates. These differences in redistribution of complexes may be related to the initial distribution of $\mathrm{Ig}$ on the surface.

Our experiments raise two fundamental questions. First, what are the prerequisites for capping, and second, by what means does a cell structure its surface membrane elements?

It has been postulated that capping may be the result of the formation of a latticework covering the cell with subsequent movement of the cell, forcing the latticework to one end, perhaps the trailing end, of the cell. This theory had received considerable support from studies in the mouse using a variety of other surface macromolecules (20). It is estimated that a single antibody molecule is capable of binding across a distance of about

${ }^{4}$ H. G. Kunkel. Unpublished observations.
$140 \AA$; thus it seems that if $\mathrm{Ig}$ is widely spaced on the membrane it could not be cross-linked and no lattice could form. Our observations on human cells are in agreement with this postulate, in that we predicted from our fluorescence studies that the cells would have a patchy Ig distribution and were able to confirm this by electron microscopy. The several thousand angstroms separating the groups of $\mathrm{Ig}$ would certainly prohibit cross-linking by either antibody or even an anti-antibody sandwich that might theoretically cross-link sites separated by about $430 \AA$. Although the use of bivalent antibody could possibly cause some aggregation of Ig sites even in cells treated at $0^{\circ} \mathrm{C}$, it seems unlikely that this effect could have significantly altered the pattern on the cell surface, since a similar patchy pattern was seen on staining with fluorescent $F a b$ fragments. In addition the results of fixing the cells before staining suggests that a granular pattern of Ig is present on the cells before complexing with antibody since the fixation seems to substantially prevent movement of $\mathrm{Ig}$ sites on the surface. Studies with Fab fragments at the electron microscopy level are in progress.

Unfortunately it has not yet been possible to satisfactorily investigate the role of cell mobility in the capping phenomenon, although it is known that active metabolism, but not protein synthesis, is necessary for capping in the mouse (12). We are unable to estimate whether decreased mobility of human cells could contribute to the explanation of infrequent capping in human lymphocytes. Nevertheless the wide separation of groups of Ig sites demonstrated here seems to be an adequate, if not necessarily complete, explanation of lack of capping.

In summary we feel that the patchy distribution of Ig on the surface of human lymphocytes precludes extensive cross-linking by antibody ligand. In addition, since complexes are rapidly lost from the surface by shedding and endocystosis, further aggregation of complexes is prevented. The end result is the formation of several distinct aggregates on the surface but no coordinated cap formation. The endocytosis of complexes and their accumulation in the vicinity of the Golgi may occasionally resemble a surface cap formation.

The fact that most human lymphocytes do not cap makes it unlikely that capping is an essential part of triggering the cell in the immune response. It is known that binding of anti-Ig to mouse cells is not a good stimulus to either DNA synthesis or production of antibody to a previously administered antigen (23). Thus capping by itself does not seem to initiate cell behavior associated with the immune response. Capping may be a mechanism, along with endocytosis, of cleaning the cell surface, or it may be an incidental phenomenon related to membrane or cell motion. 
The question of how cells maintain various configurations on their surfaces is of fundamental importance. Grouped configurations have been described for histocompatibility antigens, and other alloantigens on lymphocytes (24). In contrast to this is the evidence that some suriace elements seem to be freely diffusible on the membrane, notably in the cell fusion experiments of Frye and Edidin (25). In addition it has been shown that where movement does occur with more than one nembrane element, e.g. H-2 and Ig, it can be induced independently and the markers seem to move past each other freely (22).

The currently accepted model of membrane structure is the fluid mosaic model in which protein subunits are thought to be capable of diffusing freely in the plane of the surface separated by a fluid lipid matrix (26). This model predicts that the organization of elements into groups could be accomplished by short-range interactions between the elements, but that over larger distances the elements should be randomly arranged and freely diffusible. We have attempted in these studies to elucidate the types of interactions that might create such short-range attractions between Ig sites. The distribution of Ig on the human lymphocyte seems to be a good example of this phenomenon but we are unable as yet to explain how the groups of Ig sites are maintained. It seems likely that they are capable of movement together to form large aggregates under the influence of antibody binding, but such aggregation does not seem to occur spontaneously in the absence of a ligand, as one might expect if there were such groups of mutually attractive elements diffusing freely. It seems most likely that there is some structural element, either a part of the membrane or an anchoring structure within the cell that dictates the organization of these sites. Our efforts to alter this structure were unsuccessful and we can therefore draw no conclusions.

It is of interest to speculate what usefulness there could be to evolving grouped receptors as opposed to diffuse localization of receptors in the surface. If these Ig sites are antigen receptors, then it would be possible to increase binding affinity to antigens that naturally bear repetitive identical determinants by grouping the binding sites, whereas those determinants that occur singly or in the company of other noncross-reacting determinants would be more efficiently bound by a diffuse receptor array. Thus it might be of some value for antigen-binding cells to develop arrays of receptors for some antigens, and one might expect to see various surface configurations in various cells.

There have been reports of lymphocytic leukemias in which the majority of the cells have the same Ig class on their surface and also form what are described as typical caps on binding with anti-Ig (27). This seems to indicate that these pathological cells may have some differences in the way $\mathrm{Ig}$ is placed on their surface. These reports also add some interest to our observation of a small fraction of normal cells that are capable of capping. It is not possible to say whether these cells represent a functionally different population of B-lymphocytes, or whether they may be extreme examples of a continuous distribution of cell-surface configurations of Ig. There seems to be ample reason to pursue explanations for the behavior of Ig on the surface of both normal and neoplastic lymphocytes.

The classification of lymphocyte leukemias and lymphosarcomas by the class of Ig on the surface of the cells has revealed that many cases probably arise from proliferation of a clone of cells; however, it has not been possible to attach diagnostic or prognostic significance to the various Ig classes $(6,28-30)$. In contrast there has been some indication that the amount of Ig on the cells may be clifferent in different diseases. For example Aisenberg and Bloch comment on the increased amount of $\mathrm{Ig}$, as judged by fluorescence, which seemed to distinguish lymphosarcoma cells from chronic lymphocytic leukemia cells (31). Capping behavior may be of some use in classifying these and other lymphocytic neoplasms since it is an easily observable phenomenon related to the distribution of Ig rather than its class.

\section{ACKNOWLEDGMENTS}

The skillful assistance of Monika Leventhal and Jean Marie Kiely is gratefully acknowledged.

This study was supported by NIH Grant AI 100091 and AI 09920. Dr. Ault was supported by U. S. Public Health Service Training Grant AI 00426. Dr. Unanue is a recipient of a Research Career Award from the National Institutes of Health.

\section{REFERENCES}

1. Raff, M. C. 1970. Two distinct populations of peripheral lymphocytes in mice distinguishable by immunofluorescence. Immunology. 19: 637 .

2. Unanue, E. R., H. M. Grey, E. Rabellino, P. Campbell, and J. Schmidtke. 1971. Immunoglobulins on the surface of lymphocytes. II. The bone marrow as the main source of lymphocytes with detectable surfacebound immunoglobulins. J. Exp. Med. 133: 1188.

3. Klein, E., T. Eskeland, M. Inoue, R. Strom, and B. Johnson. 1970. Surface immunoglobulin-moieties on lymphoid cells. Exp. Cell Res. 62: 133.

4. Papamichail, M., J. C. Brown, and E. J. Holborow. 1971. Immunoglobulins on the surface of human lymphocytes. Lancet. 2: 850.

5. Froland, S. S., and J. B. Natvig. 1972. Surface-bound immunoglobulin on lymphocytes from normal and immunodeficient humans. Scand. J. Immunol. 1: 1.

6. Grey, H. M., E. Rabellino, and B. Pirofsky. 1971. Immunoglobulins on the surface of lymphocytes. II. Distribution in hypogammaglobulinemias, cellular immune deficiency, and chronic lymphatic leukemias. J. Clin. Invest. 50: 2368. 
7. Siegel, F. P., B. Pernis, and H. G. Kunkel. 1971. Lymphocytes in human immunodeficiency states, a study of membrane associated immunoglobulins. Eur. J. Immunol. 1 : 482.

8. Unanue, E. R., and M. J. Karnovsky. 1973. Redistribution and fate of immunoglobulin complexes on surface of B-lymphocytes: functional implications and mechanisms. Transplant. Rev. 14: 184.

9. Unanue, E. R., W. D. Perkins, and M. J. Karnovsky. 1972. Ligand-induced movement of lymphocyte membrane macromolecules. I. Analysis of immunofluorescence and ultrastructural autoradiography. J. Exp. Med. $136: 885$.

10. Loor, F., L. Forni, and B. Pernis. 1972. The dynamic state of the lymphocyte membrane: factors affecting the distribution and turnover of surface immunoglobulins. Eur. J. Immunol. 2: 203.

11. Taylor, R. B., W. P. H. Duffus, M. C. Raff, and S. dePetris. 1971. Redistribution and pinocytosis of lymphocyte surface immunoglobulin molecules induced by anti-immunoglobulin antibody. Nat. New Biol. 23.3: 225.

12. Unanue, E. R., M. J. Karnovsky, and H. D. Engers. 1973. Ligand-induced movement of lymphocyte membrane macromolecules. III. Relationship between the formation and fate of anti-Ig-surface Ig complexes and cell metabolism. J. Exp. Med. 137: 675 .

13. Engers, H. D., and E. R. Unanue. 1973. The fate of anti-Ig surface Ig complexes on B-lymphocytes. $J$. Immunol. 110: 465.

14. Perper, R. J., T. W. Zee, and M. M. Mickelson. 1968. Purification of lymphocytes and platelets by gradient centrifugation. J. Lab. Clin. Med. 72: 842 .

15. Perkins, W. D., M. J. Karnovsky, and E. R. Unanue. 1972. An ultrastructural study of lymphocytes with surface-bound immunoglobulins. J. Exp. Med. 135: 267.

16. Porter, R. R. 1959. The hydrolysis of rabbit $\gamma$-globulin and antibodies with crystalline pepsin. Biochem. J. 73: 119.

17. Marchalonis, J. J. 1969. An enzymic method for the trace iodination of immunoglobulins and other proteins. Biochem. J. 113: 299.

18. Martin, R. G., and B. N. Ames. 1961. A method for determining the sedimentation behavior of enzymes: application to protein mixtures. J. Biol. Chem. 236: 1372.
19. Ram, J. S., S. S. Tawde, G. B. Pierce, Jr., and A. R. Midgley, Jr. 1963. Preparation of antibody-ferritin conjugates for immuno-electron microscopy. J. Cell Biol. $17: 673$.

20. Unanue, E. R., W. D. Perkins, and M. J. Karnovsky. 1972. Endocytosis by lymphocytes of complexes of antiIg with membrane-bound Ig. J. Immunol. 108: 569.

21. Ukena, T. E., and R. D. Berlin. 1972. Effect of colchicine and vinblastine on the topographical separation of membrane functions. J. Exp. Med. 136: 1 .

22. Preud'homme, J. L., C. Neauport-Sautes, S. Piat, D. Silvestre, and F. M. Kourilsky. 1972. Independence of HL-A and Ig determinants on the surface of human lymphoid cells. Eur. J. Immunol. 2: 297.

23. Katz, D. H., and E. R. Unanue. 1972. The immunological capacity of lymphocytes after cross-linking of surface immunoglobulin receptors by antibody. J. Immunol. 109: 1022.

24. Karnovsky, M. J., E. R. Unanue, and M. Leventhal. 1972. Ligand-induced movement of lymphocyte membrane macromolecules. II. Mapping of surface moieties. J. Exp. Med. 136: 907.

25. Frye, L. D., and M. Edidin. 1970. The rapid intermixing of cell surface antigens after formation of mouse-human heterokaryons. J. Cell. Sci. 7: 319.

26. Singer, S. J., and G. L. Nicholson. 1972. The fluid mosaic model of the structure of cell membranes. Science (Wash. D. C.) 175: 720 .

27. Johansson, B., and E. Klein. 1970. Cell surface-localized IgM-Kappa immunoglobulin reactivity in a case of chronic lymphocytic leukemia. Clin. Exp. Immunol. 6: 421.

28. Piessens, W. F., P. H. Schur, W. C. Moloney, and W. H. Churchill. 1973. Lymphocyte surface immunoglobulins: distribution and frequency in lymphoproliferative diseases. N. Engl. J. Med. 288: 176.

29. Preud'homme, J. L., and M. Seligman. 1972. Anti-human immunoglobulin $\mathrm{G}$ activity of membrane-bound monoclonal immunoglobulin $M$ in lymphoproliferative disorders. Proc. Natl. Acad. Sc. U. S. A. 69: 2132.

30. Preud'homme, J. L., and M. Seligman. 1972. Surfacebound immunoglobulins as a cell marker in human lymphoproliferative diseases. Blood J. Hematol. 40: 777.

31. Aisenberg, A. C., and K. J. Bloch. 1972. Immunoglobulins on the surface of neoplastic lymphocytes. N. Engl. J. Med. $287: 272$ 